\title{
Agriculture Phenomena and Perspectives of Lebak Swamp in Jakabaring South Sumatra, Indonesia
}

\author{
Elisa Wildayana ${ }^{1}$, M. Edi Armanto ${ }^{2}$ \\ 1. Agribusiness Study Program, Faculty of Agriculture, Sriwijaya University \\ 2. Soil Science Study Program, Faculty of Agriculture, Sriwijaya University \\ E-mail: ewildayana@unsri.ac.id, mediarmanto@unsri.ac.id
}

Received: May 25, 2017; Accepted: August 18, 2017; Published: November 3, 2017

Permalink/DOI: http://dx.doi.org/10.17977/um002v9i22017p166

\begin{abstract}
The research aimed to analyze agriculture phenomena and perspectives of lebak swamp in Jakabaring South Sumatra Indonesia. The research used mix methods of quantitative and qualitative approaches. The description of the research area was assisted with interpretation of Landsat images in 1987 and 2015. The research resulted that farmer's groups living in Jakabaring are divided into four group, namely indigenous people (people of Ogan, Komering, Musi, Enim, and Palembang), new comers (Javanese), spontaneous migration (Buginese, Banjarnese, Bataknese) and outside spontaneous migration (Chinese, Arabic). The total area of Jakabaring is approximately 5,525 ha, around 2,700 ha $(48.87 \%$ ) was already landfilled by the Government in 1990 , while the remaining 2,825 ha $(51.13 \%)$ is still not reclaimed. The landfill materials were directly sucked from mud, sand, silt and stones of the Musi River. Each lebak swamp typology shows specific soil characters, but after landfills all soils became homogenous because of uniform materials of landfills. Patterns of land degradation after landfills are classified into three groups, namely making layers of water impermeability, changing vegetation types of land cover, and decreasing type and density of vegetation.
\end{abstract}

Keywords: Agriculture, phenomena, perspectives, lebak, swamp JEL Classification: O13, Q01

\section{INTRODUCTION}

Lebak swamp in South Sumatra has an area of approximately 1.1 million ha or 11\% of South Sumatra Province (Direktorat Rawa and Pantai, 2009). Most of lebak swamp is utilized not on the basis of its balance ecosystem sensitivity or do not touch on some upstream ecosystems which always influence negative impact to the whole dynamics of lebak swamp. Lebak swamp demands are always focused on the economic and physical development potential (i.e. building, infrastructure, common facilities etc.), therefore it should be balanced with a strong understanding of lebak ecosystems ranging from upstream to downstream (Sjarkowi et al., 2007; Wildayana, 2014, 2015). One of the easiest example of lebak swamp uses for the economic and physical development is to reclaim by doing landfills (Wildayana et al., 2008; Armanto et al., 2010; 2013; Adriani, 2013; Pogue, 2004).

Jakabaring landfills could have a positive and negative impacts for lebak swamp ecosystem, especially in areas of directly affected rice fields (Armanto, 2014). The landfills are done with the main objective for the development of upstream areas of the Palembang city. However, these landfill activities pay less attention to agriculture aspects, especially Jakabaring as one of the rice production 
originating from lebak swamp. Less attention to the agricultural sector has caused the rice production progressively decreased and the rice fields are less attended not only by the government but also by the local community.

Homogenous landfill materials were taken from the Musi River and mostly consist of sand, dust and rock fractions. Landfills of rice fields can change instantly into dry land and plants were totally destroyed due to landfill material accumulation. These conditions have implications for farmers who rely on their main earnings from agricultural production, especially rice fields because the rice fields cannot be used anymore as agricultural production media.

According to theory, landfills of lebak swamp can potentially improve soil fertility if the materials from river sediment as landfilling materials contain a variety of useful nutrients for the growth of agricultural crops. But as we all know that most of the river sediment contains a lot of sand which is rich in silica and some elements are still in the form of both primary and secondary mineral that takes time to process long-term weathering, so that the release of these nutrients become available to plants. In general, because the material is rich of sand, then these materials lack the holding capability of certain nutrients and water as well as easy to get carried away by surface runoff.

Jakabaring can be said that the area is experiencing rapid process of flooding and drying problems as well as nutrient leaching. To get detailed information, so that the land can be cultivated for agricultural purposes, it is necessary to do research with the aim to analyze agriculture phenomena and perspectives of lebak swamp in Jakabaring South Sumatra. The research results are expected to be input for the government what action needs should be done to restore the lebak swamp resources in Jakabaring region.

\section{METHOD}

The research was carried out in Jakabaring which is cited in the Southern part of Palembang, South Sumatra. The research used mix methods of quantitative and qualitative approaches. The description of the research area was assisted with interpretation of Landsat images in 1987 and 2015. The interpretation of research area was supported by thematic maps of RePPProt (1988) and topographic map with scale of 1:50,000, soil map with scale of 1:250,000, wetland map with scale of 1:500,000 as well as the planimetric calculation of the research area (Figure 1). The research was using survey method in the fields. Soil samples and respondents were taken by randomly purposive sampling. The field observations and interviews with local people were carried out by open questionnaire. All collected data are analyzed, described and performed in table forms and narrative descriptions.

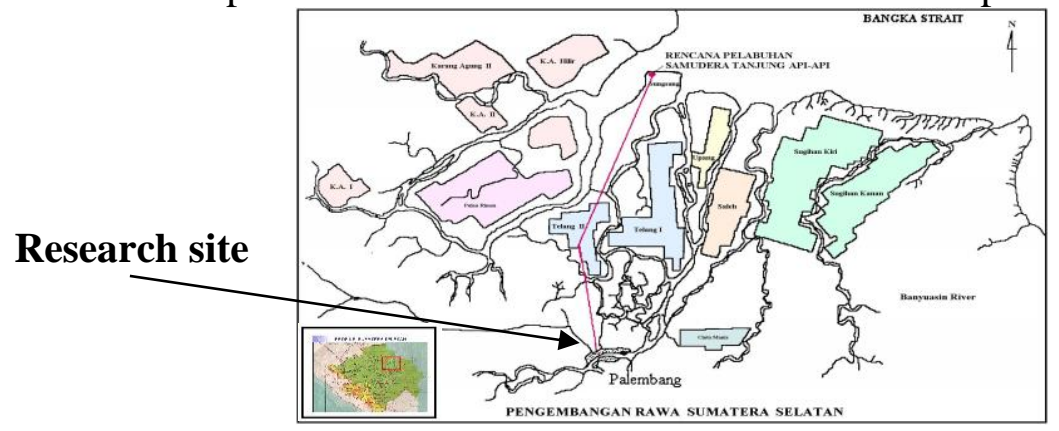

Figure 1. Research site in Jakabaring Palembang (Direktorat Rawa \& Pantai, 2009) 
Lebak swamp landfills analyzed from the agricultural sectors will discuss about (1) farmer's groups and tribes activity of lebak swamp before 1970, (2) land reclamation history of lebak swamp before 1970, (3) land reclamation history of lebak swamp after 1990, (4) landfill impacts on soil characters, and (5) and patterns of land degradation.

\section{RESULT AND DISCUSSION}

Results and discussion focus on the following topics, namely farmers groups and tribes activity of lebak swamp before 1970, land reclamation of lebak swamp before 1970, land reclamation of lebak swamp after 1990, and patterns of land degradation.

\section{Farmers Groups and Tribes Activity of Lebak Swamp before 1970}

Administratively a part of Sub district Seberang Ulu I initially before 1970 was called as Jakabaring and this area belongs to the strategic area in Southern part of Palembang city. Activities of farmers in this lebak swamp were strongly influenced by daily tides of the Musi river and the Ogan river that determined agricultural activity as lebak rice fields. Jakabaring before 1970 was populated by the heterogeneous tribes and composed of various different groups with specific occupations. The tribes occupying Jakabaring before 1970 was closely related to the life history of spontaneous migration from outside South Sumatra. The linkage between farmer's groups with their occupations is summarized in Table 1.

Table 1. The linkage between farmer's groups with their occupations

\begin{tabular}{|c|c|c|c|}
\hline $\mathrm{Nr}$ & Farmer's group & Tribes & Main occupations (livelihood) \\
\hline 1 & $\begin{array}{l}\text { Indigenous } \\
\text { people }\end{array}$ & $\begin{array}{l}\text { Ogan, Palembangnese, } \\
\text { Musi, Komering, Enim }\end{array}$ & Rice fields, fisheries, trading \\
\hline 2 & $\begin{array}{l}\text { Spontaneous } \\
\text { migration }\end{array}$ & $\begin{array}{l}\text { Buginese, Banjarnese, } \\
\text { Bataknese }\end{array}$ & Rice fields, coconut, fisheries \\
\hline 3 & New comers & Javanese & $\begin{array}{l}\text { Sharecroppers, rice fields, } \\
\text { fisheries }\end{array}$ \\
\hline 4 & $\begin{array}{l}\text { Outside spontaneous } \\
\text { migration }\end{array}$ & Chinese, Arabic & $\begin{array}{l}\text { Trading, fish processing, } \\
\text { fisheries }\end{array}$ \\
\hline
\end{tabular}

Source: Field survey (2016) and modified from Scholz (1985).

Indigenous people (original settlers) living along Musi River are the Malay people and named according to the rivers flowing to the areas where they settle, namely the Ogan people, the Komering people, the Musi people, the Enim people as well as the Palembangnese and others. Indigenous people are generally settled exclusively along the major rivers and in the river levee with high soil nutrients, thus these areas were suitable for crop production. They cultivated rice fields, fisheries, and only the Palembangnese have a specific occupation as trading people. Most of their political and economic role was almost neglected. They were commonly able to produce enough foods for their living standard as subsistence farming. Although they were relatively rich enough, their environmental conditions were not enough attractive for new comers (Javanese) to collaborate together in agricultural business.

Spontaneous migrations are divided into tribes of the Buginese (coming from South Sulawesi), the Banjarnese (from Kalimantan) and the Bataknese from 
North Sumatra. Land and water management techniques of swamp area were firstly pioneered by the Buginese farmers on the Eastern part of Sumatra. They have been learning the swamp techniques from Banjarnese. At the first time (around last 150200 years ago), Buginese arrived in areas between the Batanghari River and delta of Indragiri, Riau. Since that time, they have successfully transformed an area of more than 300 thousands ha of agricultural land cultivated as rice fields and coconut (Scholz, 1985). They are able to keep their position as independent farmers and fisherman, although they belonged to an only minority with respect to political and economic powers. Their main occupations are rice fields, coconut estate as well as fisheries. Unlike other tribes, the Buginese always work together in well-organized groups without any supports and any intervention of the government. They want to highlight the group success rather than individual achievements. After harvesting forest products such as logs, the Buginese cultivated rice in lebak swamp and the same time they plant coconuts in areas that have been drained or in river levee. After the coconut estate become productive, many of them leave their rice fields or coconut estate and lease the fields to Javanese, then they are living in cities becoming landlords. In general the Buginese belong to moderate rich people in South Sumatra.

New comers belong to tribe of Javanese people and they have very different characters with other people. On first Javanese arrival, they grow rice in Belitang followed transmigration program in Dutch Colonization and cultivated coffee in the Bukit Barisan. The next generation of the Javanese moved to lebak swamp and most of them live in scattered areas along the Musi River and the Ogan River. Some Javanese arrived in Jakabaring area as spontaneous migrants directly from Java or second generations of transmigration and work as sharecroppers in the rice fields of the indigenous people and fisheries. Gradually the indigenous people purchase their land to the Javanese and they began to start subsistence farming (rice fields) and follow the indigenous people to plant rubber as well as coconut.

Outside spontaneous migration is other ethnic group from outside of Indonesia. Most of them were spontaneous immigrating people during last century come from China and Arabic countries, i.e. Chinese and Arabic with occupation as trading, fish processing as well as fisheries. They work mostly to downstream business of all agricultural products. They live mostly in scattered areas along the Musi River and Ogan River, especially in crowded areas, namely local markets, areas where farmers gathered for buying and selling, near oil pump station, areas at the crossroads, and so on.

According to a field survey results, before landfills (1970) about $37 \%$ of inhabitant was as farmers (rice fields), about $35 \%$ acted as fishermen (fisheries), around $5 \%$ as agricultural fields and coconut estate and the rests $(23 \%)$ were various occupations. After landfills by the government, most of the indigenous people, spontaneous migration as well as new comers (Javanese) moved to the suburbs or changed their occupation as other than farmers. Works chosen by the Javanese are anything as long as they are able to earn some money for their life, other people become day labors, seasonal labors, carpenters, beca, porters, port labors, drivers, small and local merchants and any others, while the Chinese and the Arabic tribes survive in their livelihood (trading, fish processing and fisheries) live at the same places. 


\section{Land Reclamation of Lebak Swamp before 1970}

History of lebak swamp reclamation before 1970 is summarized by Scholz (1985) and simply presented on the map in Figure 2 (spontaneous settlement by Javanese) and Figure 3 (spontaneous settlement by the Buginese). The Javanese migration was firstly supported by government intervention, however, the Buginese migration was not interfered by any governmental institutions.

The second generation of Javanese moves to lebak swamp area because based on the experience of their predecessor generation that standard plot size in transmigration project (two hectares) is not enough to ensure a livelihood for the second generation, thus the second generation expand their agricultural farms and moved to lebak swamp area. One of lebak swamp destination is Jakabaring area. After deciding to move to the lebak swamp, then the Javanese will remain forever.

Actually, the Buginese and indigenous people were the initiator of land clearing for lebak swamp forest in Jakabaring, and then employed some Javanese as sharecroppers, contract farmers, and at the end they sold the lands for them. Furthermore, the Javanese build their own communities in lebak swamp. Unfortunately only little of the Javanese migrants are successful in Jakabaring because the majority of Javanese have changed occupations into seasonal workers, peasants, subsistence farmers, small farmers, drivers, local and small traders, shaving and others.

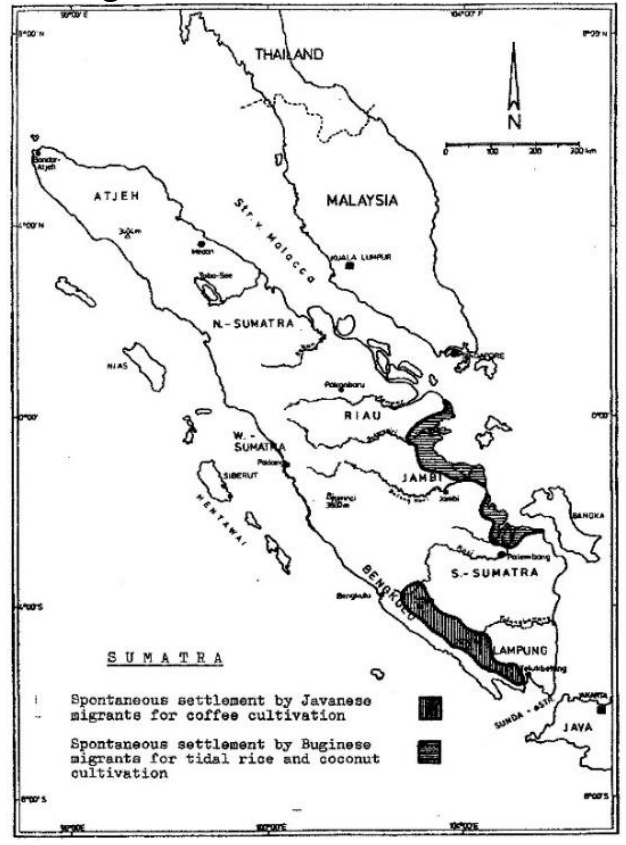

Figure 2. Spontaneous settlement by the Javanese (Scholz, 1985)

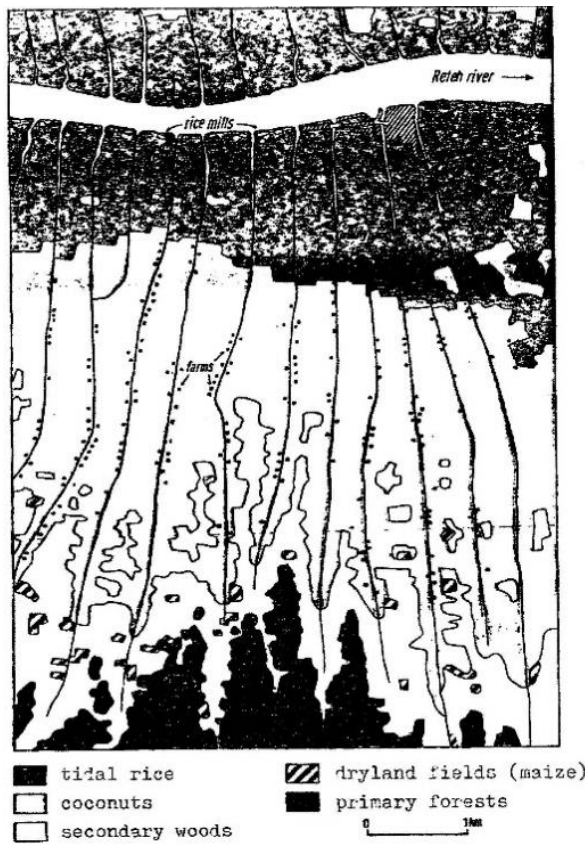

Figure 3. Spontaneous settlement by the Buginese (Scholz, 1985)

Since 1965 the Buginese people have intensively expanded their activities further to the Southern part of Sumatra, namely to Delta Musi (downstream of Palembang city including Jakabaring). Buginese's work can be considered as one of the major successes converting swamps into agricultural swamp land. However their main motive coming to swamps in South Sumatra was not primary for agricultural purposes, but they wanted to harvest forest log and would be traded to Java using Buginese unique boat. After log harvest, the lands were cleared and directly converted to agricultural lands as rice fields. Thus Buginese were 
mentioned as the pioneers for swamp land clearing and made agricultural business in the swamp area.

Land clearing was carried out in scheme as follows; every $500 \mathrm{~m}$ along the main rivers, Buginese people made and dig a channel for logs transport from the forest. The canal lies on the right side and perpendicular to the main river up to several kilometers inland swamp (lebak swamp). Each primary channel is connected again periodically with the secondary channel running parallel to the rivers (Figure 3). The Buginese cut the trees and did not burn the land for land clearing.

The river water will be dammed by the sea waves and river water was detained through the canal system. At the peak of the rainy season, the whole area flooded and become dry during the dry season. It can be mentioned that this system is able to combine irrigation and drainage respectively. Rice fields are generally cultivated in the river levee and followed by planting coconut.

Rice yields in the first year were usually below average and the best yields were reached in the third and fourth year, the fifth year and so on the rice yields would decline due to interruption of weeds. The first unproductive years were financially supported by log trading. After six to eight years, most of the Buginese farmers will abandon their rice fields and they concentrate on the coconut cultivation or moved to upstream in order to open new areas. Another alternative that they gave the land to next generation or new comers. New comers are mostly consisting of spontaneous Javanese migrants who are willing to implement laborintensive methods, for example digging (something Buginese never do). The purpose of digging is to suppress growth of weeds. Buginese people often become landlords because they are able to open up dozens of hectares of swamp forest for rice fields and coconut. Buginese farmers have an average land of about 3.0 ha, which is double the average of the land area to all farmers in South Sumatra, thus the income of Buginese people was above average or higher above the standard of all farmers in South Sumatra.

Around 1970 to 1988, lebak swamp in Jakabaring is left abandoned as fallow land. Farmers are less motivated to cultivate lebak swamp. It is not only mostly caused by physical, chemical and biological factors, but also due to socioeconomic and cultural factors. Besides that Governmental support for agricultural activity in Jakabaring was also limited.

\section{Land Reclamation of Lebak Swamp after 1990}

In the year 1989-1998, monumental programs were carried out by the Governor of South Sumatra named as the Regional Control Program of Swamp Project. This project dialed with Jakabaring landfills by using mud, sand, silt and small stones from the Musi River pumped to Jakabaring swamp. The end result of the program (in 1997), it was produced a territorial area of almost 2,700 ha (48.25 $\%$ ) of the total Jakabaring area (5.525 ha), while the remaining area is still not yet reclaimed (around 2,825 ha or $51.13 \%$ ). In Jakabaring, the governmental office centers, International sports centers, industry, and settlements are built and concentrated. Extensive landfills in Jakabaring are presented in Table 2.

The majority lebak owners used lebak swamp for rice fields, agricultural fields, small estate, coconut and vegetable gardens. Although most of lebak swamp has been used to fulfill basic need of local people's life, it is still enough lebak 
swamp area called as non-productive lands in the form of sleeping land, abounded land, swamp bush with any kinds of natural vegetation, namely gleam forest, belidang grass, perumpung and others.

Landfills of lebak swamp influenced on direct and indirect impacts on the landscape physically, socially and economically and the whole society. It resulted in land use change from cultivated lebak into man-made ecosystem. It caused diminishing acreages of agricultural land to non-agricultural land. These land uses changes will continue in line with increased economic growth, thus in the future, it is estimated that land-use change will occur with accelerated speed. If there are no control regulations, these land uses changes may lead misallocation problems of regional development and it is possible that some physical development will be placed not on its allocation.

Table 2. Landfills zone of lebak swamp in Jakabaring

\begin{tabular}{clcc}
\hline $\mathrm{Nr}$ & \multicolumn{1}{c}{ Land uses } & Acreage (ha) & Percentage (\%) \\
\hline 1 & Landfills (lebak reclamation) & 2,700 & 48.87 \\
2 & Natural condition & 2,825 & 51.13 \\
\hline \multicolumn{2}{l}{ Total } & 5,525 & 100.00 \\
\hline
\end{tabular}

Note: Indonesian topographical map scale of 1: 50,000, administrative map of Palembang scale 1: 250,000, Landsat images 2015 and field survey (2016).

Before landfills, overall most shallow lebak swamp were classified as fertile soils compared with those in other typologies, because their soil $\mathrm{pH}$ value, Base Saturation (BS), Cation Exchange Capacity (CEC) and available P showed the highest values and ground water level was $<25 \mathrm{~cm}$ happening only $<3$ months per year. However in lebak lebung, soil texture is difficult to determine because the dominance of organic material disturbed soil texture analyses (organic $\mathrm{C}$ content of 20-55\%). High organic matter stimulated also very high CEC. The main problem of lebak lebung is high content of organic matter and the lands are always flooded that can inhibit plant growth, so that farmers are generally not able to manage lebak lebung except only for natural fishery alone (Table 3).

Table 3. General soil assessment of soil characters ${ }^{1 /}$

\begin{tabular}{lccccc}
\hline Lebak types & $\mathrm{pH}^{\mathrm{H}-}$ & $\begin{array}{c}\mathrm{BS} \\
(\%)^{2 /}\end{array}$ & $\begin{array}{c}\mathrm{CEC} \\
(\mathrm{me} / 100 \mathrm{~g})^{3 /}\end{array}$ & $\begin{array}{c}\mathrm{P}_{2} 0_{5} \\
(\mathrm{ppm})\end{array}$ & $\begin{array}{c}\text { Organic C } \\
(\%)\end{array}$ \\
\hline Lebak lebung & $3.4-3.9$ & $4.2-14$ & $33-55$ & $3.9-5.9$ & $20-55$ \\
& $(\mathrm{va})$ & $(\mathrm{vl})$ & $(\mathrm{h}-\mathrm{vh})$ & $(\mathrm{vl})$ & $(\mathrm{vh})$ \\
Deep lebak & $4.0-4.3$ & $30-35$ & $32-59$ & $0.6-5.0$ & $5.7-15.5$ \\
& $(\mathrm{va})$ & $(\mathrm{l})$ & $(\mathrm{h}-\mathrm{vh})$ & $(\mathrm{vl})$ & $(\mathrm{vh})$ \\
Middle lebak & $4.2-5.1$ & $32-35$ & $16-20$ & $2.5-11.5$ & $3.6-12.5$ \\
& $(\mathrm{a}-\mathrm{va})$ & $(\mathrm{l})$ & $(\mathrm{m})$ & $(\mathrm{vl})$ & $(\mathrm{h}-\mathrm{vh})$ \\
Levee lebak & $4.6-5.4$ & $33-51$ & $17-21$ & $4.3-12.3$ & $2.3-6.4$ \\
& $(\mathrm{a})$ & $(1-\mathrm{m})$ & $(\mathrm{m})$ & $(\mathrm{vl}-1)$ & $(\mathrm{m}-\mathrm{h})$ \\
Shallow lebak & $5.2-5.7$ & $31-60$ & $18-22$ & $5.4-12.7$ & $1.7-6.5$ \\
& $(\mathrm{a}-\mathrm{la})$ & $(1-\mathrm{m})$ & $(\mathrm{m})$ & $(\mathrm{vl}-\mathrm{l})$ & $(\mathrm{l}) \mathrm{vh})$ \\
After landfills & $4.7-5.5$ & $30-63$ & $16-24$ & $4.0-14.5$ & $1.5-6.8$ \\
& $(\mathrm{a})$ & $(\mathrm{l}-\mathrm{h})$ & $(\mathrm{m})$ & $(\mathrm{l})$ & $(\mathrm{l}-\mathrm{vh})$ \\
\hline
\end{tabular}

Note $:{ }^{1 /}$ The assessment is empirically based only on the general soil nature and has not been linked to the crop needs.

${ }^{2 /}$ BS (Base Saturation), ${ }^{3 /}$ CEC (Cation Exchange Capacity); va (very acid); a (acid); la (little acid); vl (very low); 1 (low); m (medium); h (high); vh (very high) 
After landfills, all lands derived from all typologies become homogenous because of landfills using relatively uniform materials from the Musi River. Thus landfills produce relatively uniform soil characters also where the soil $\mathrm{pH}$ becomes slightly increase to 4.7-5.5 (acid), BS (base saturation) value is more or less the same, namely 30-63\% (low to high), CEC (cation exchange capacity) has slightly decreased around 16-24 me/100 g (medium), $\mathrm{P}_{2} 0_{5}$ was relatively stable 4.0-14.5 ppm (low). Organic $\mathrm{C}$ decreased drastically to landfills activity, although it is still classified as high as 1.5-6.8 \% (low to very high). CEC was declining in line with the decreasing in soil organic matter. It can be concluded that the chemical fertility of the soil caused a decline in some of the soil properties. It can be understandable because most organic materials have holding capacity to absorb soil nutrient if active decomposition of organic material caused some soil nutrient released from its complex. If these process occurs continuously without any control, it is possible to accelerate land degradation and stimulate formation of critical lands.

\section{Patterns of land degradation}

Land use changes can threaten the existence of groundwater levels because land use changes can cause lowering groundwater levels, though the main source of ground water comes from rain water. Rainwater infiltration through infiltration plays an important role because it determines the sustainability of the groundwater system, so the disruption of water infiltration can result in a decrease in soil water potential. Patterns of land degradation are very varied and there are three patterns of land degradation in Jakabaring. Each pattern shows namely different characteristics in terms of actors, total area and their impact (Table 4).

Table 4. Patterns of land degradation after landfills in Jakabaring

\begin{tabular}{|c|c|c|c|c|}
\hline \multirow[t]{2}{*}{$\mathrm{Nr}$} & \multirow[t]{2}{*}{ Degradation pattern } & \multirow[t]{2}{*}{ Actors } & \multicolumn{2}{|c|}{ Area coverage } \\
\hline & & & ha & $\%$ \\
\hline 1 & $\begin{array}{l}\text { Making layers of } \\
\text { water impermeability }\end{array}$ & $\begin{array}{l}\text { Government, businessman, } \\
\text { strong financier }\end{array}$ & $1,548.45$ & 57.35 \\
\hline 2 & $\begin{array}{l}\text { Changing vegetation } \\
\text { types of land cover }\end{array}$ & Land speculator, strong society & 750.33 & 27.79 \\
\hline 3 & $\begin{array}{l}\text { Decreasing type and } \\
\text { density of vegetation }\end{array}$ & Farmers and local people & 401.22 & 14.86 \\
\hline & & Total & 2,700 & 100.00 \\
\hline
\end{tabular}

Note: Indonesian topographical map scale of 1: 50,000, administrative map of Palembang scale 1: 250,000, Landsat images 2015 and field survey (2016).

The first pattern of land degradation is named as making layers of water impermeability. Water impermeability means that water is not able to penetrate soils vertically because some impermeable layers in soils are formed. Its formation is stimulated through land use changes from agricultural land into non-agricultural land, for example into industrial land or settlements, international sports centers and others. This impermeability layers are generally carried out by powerful financiers, authorities, state officials with a very wide area with impermeable surface characteristics which cannot pass water. Land damage through this pattern covers large coverage of a total area about $1,548.45$ ha $(57.35 \%)$, for example through landfills and soil compaction and hardening. 
Based on the field research results and monitoring by using Landsat images, this first pattern is very difficult to be prevented and controlled both by the government and the public, because the developing actors generally have strong access to policy makers both at the central, provincial and district or city levels. With the formation of impermeable layers, it will have a direct impact on the occurrence of floods and droughts and decreased water production which should have been infiltrated into the ground water, but water run on the surface as surface runoff. The decrease impact in water production capacity will lead to widespread floods and water shortage in Jakabaring. The first pattern shows the most damaging effect on the overall hydrological cycle, water production and in the long term leading to acute water crisis (prolonged water shortage). All of this will enhance the formation of a layer of impermeable surface soil.

The second pattern of land degradation is called as changing vegetation types of land cover. Changes in land cover vegetation types are commonly initiated by people who wanted to have some land (including land speculators). This pattern is as a result of the distribution, allocation and unequal land ownership in the general population. The developing actors behind this pattern are powerful investors (who wanted to take control of state land) or strong people, for example some lands are kept as a scrub or secondary forest or abandoned land dominated by alang-alang grass. Land degradation through this pattern is around 750.33 ha $(27.79 \%)$. It is usually found on land that has a high economic value.

The third pattern of land degradation is determined as decreasing the type and density of vegetation. A decrease in the vegetation type and density is generally carried out by the local communities surrounding the swamp forest to meet their basic living needs of firewood and their capability for land clearing are simply limited. Land degradation through this type is approximately only 401.22 ha (14.86 $\%)$. Therefore making governmental policy should be started with the first pattern how to manage Jakabaring, instead of the second or third patterns. If the first pattern can be managed properly, then the second and third patterns will automatically be easier to be controlled because the real coverage area of the second and third patterns are relatively limited.

\section{CONCLUSION}

Based on the results of research and discussion, it can be drawn some conclusions as follows: The farmer's groups living in Jakabaring are divided into four group, namely indigenous people (Ogan, Komering, Musi, Enim, Palembangnese), new comers (Javanese), spontaneous migration (Buginese, Banjarnese, Bataknese) and outside spontaneous migration (Chinese, Arabic). The total area of Jakabaring is approximately 5,525 ha, around 2,700 ha (48.87\%) was already landfilled by government in 1990 , while the remaining 2,825 ha $(51.13 \%)$ is still not reclaimed. The landfill materials were directly sucked from mud, sand, silt and stones of the Musi River. Each lebak swamp typology shows specific soil characters, but after landfills all soils became homogenous because of uniform materials of landfills. Patterns of land degradation after landfills are classified into three groups, namely making layers of water impermeability, changing vegetation types of land cover, and decreasing type and density of vegetation. 


\section{ACKNOWLEDGEMENTS}

The author would like to say many thanks to Sriwijaya University who has provided assistance and financial support to the research implementation. Thanks are also expressed to the staff and students of the Faculty of Agriculture, Sriwijaya University who has permitted and facilitate the research in the fields.

\section{REFERENCES}

Adriani, D. (2013). Ethnic and Women Farmer Participation Rate on Tidal Land in South Sumatra, Indonesia. International Journal of Humanities and Management Sciences (IJHMS), 1(3), 225-227.

Armanto, M.E., Syahrial, Susanto, R.H., \& Probowati, D. S. (2010). Spatial Analyses of Landuse Changing in Tidal Lowland Areas (A Case Study of Saleh Delta Areas in Banyuasin District, South Sumatra). Proceedings of the International Seminar-Workshop on Integrated Lowland Development and Management, $18^{\text {th }}-20^{\text {th }}$ March 2010, Palembang, Indonesia. p. A6-1 A6-10.

Armanto, M.E., Adzemi, M.A., Wildayana, E., \& Imanudin, M.S. (2013). Land Evaluation for Paddy Cultivation in the Reclaimed Tidal Lowland in Delta Saleh, South Sumatra, Indonesia. Journal of Sustainability Science and Management, 8 (1), 32-42.

Direktorat Rawa \& Pantai. 2009. Potensi dan Tantangan Pengembangan Rawa Indonesia. Makalah pada Seminar Lokakarya Pengelolaan Rawa dalam Mendukung Ketahanan Pangan Nasional. Departemen Pekerjaan Umum. Hotel Nikko Jakarta.

Pogue, M. (2004). Investment Appraisal: A New Approach. Managerial Auditing Journal, 19(4), 565-570.

RePPProt. 1988. Review of phase 1 results: Sumatra. Land Resources Department, Natural Resources Institute, London and Departemen Transmigrasi, Jakarta.

Scholz, U. (1985). Spontaneous Rural Settlements and Deforestation in Southeast Asia; Examples from Thailand and Indonesia. Paper for the International Seminar on "Planning for Settlements in Rural Regions; The Case of Spontaneous Settlements" organized by United Nations Center for Human Settlements (Habitat), Nairobi/Kenya 11-20 November 1985

Sjarkowi, F., Arbain, A., Armanto, M.E., Santoso, U., Arjuna, J., Rifardi., Setiawan, A., Syahrul, J., Khairijon., \& Azizah. (2007). Environmental Quality of Sumatra Island 2007. Center for Regional Environmental Management, Sumatra, State Ministry for Environment, Republic of Indonesia, Pekanbaru, Riau, p. 393.

Wildayana, E., Armanto, M.E., \& Rahmawati, N. (2008). Pengembangan Program Pola Usahatani Agribisnis Spesifik Lokasi di Lahan Pasang Surut. Journal of Habitat, XIX (3), 223-236.

Wildayana, E. (2014). Formulating Oil Palm Investment Decision in Tidal Wetlands of South Sumatra, Indonesia. Journal of Wetlands Environmental Managements (JWEM), 2(2), 30-36.

Wildayana, E. (2015). Formulating Rice Fields Conversion Control to Oil Palm Plantations in Tidal Wetlands of South Sumatra, Indonesia. Journal of Wetlands Environmental Managements (JWEM), 3(2), 72-78. 